\title{
Kenneth Osgood and Derrick E. White (eds.), Winning While Losing: Civil Rights, the Conservative Movement and the Presidency from Nixon to Obama (Gainesville: University Press of Florida, 2014, \$79.95. Pp. 304; 978-0-8130-4908-3)
}

Histories of the African-American freedom struggle have typically presented the civil rights politics of the last half-century as a zero-sum game, in which the setbacks suffered by civil rights advocates have been matched, almost stride for stride, by the growing ascendancy of political conservatism. ${ }^{1}$ Kenneth Osgood and Derrick White's new edited collection on the intersection between civil rights and an increasingly conservative executive offers a muchneeded corrective to this narrative, by outlining the 'paradox' of 'winning while losing' in a post-civil rights era. Civil rights activists could still win in a period of conservative governance and electoral predominance, the book argues, only in narrower, more limited terms. Equally, conservatives' attempts to limit or roll back those victories were often resisted, or even thwarted, in a landscape transformed by the civil rights revolution of the 1960s. Such a paradox explains why we can celebrate the achievement of formal and political equality, the longevity of racially redistributive policies such as affirmative action, and the presence of an African-American in the White House for two consecutive terms, and yet at the same time acknowledge that Martin Luther King's dream of socio-economic equality and an assault on the structural problems of race and racial discrimination remains as elusive and incomplete as ever.

The focus of Winning While Losing is on presidential politics, and the book's ten essays, covering nearly every presidency from Nixon to Obama (George H.W. Bush is the only absentee), expertly link executive decision-making and electoral strategizing with the politics of civil rights. They chart the redirection of civil rights advocacy away from Congress, the Supreme Court or public debate towards what Osgood and White call 'the shadows' - the courts, bureaucracy and federal agencies; a trend which enabled conservatives to pack and politicise such institutions and thus limit or even reverse old legal precedents and definitions. They illustrate the emergence of a new conservative discourse on race, implicitly rather than explicitly racialised, which utilised decreasing public support for government intervention and regulation - the traditional engines of civil rights reform - to limit and restrict civil rights

\footnotetext{
${ }^{1}$ For examples, see Harvard Sitkoff, The Struggle for Black Equality (New York: Hill \& Wang, 2008), pp. 210236; Robert J. Norrell, The House I Live In (New York: Oxford University Press, 2006), pp. 269-302; Stephen Steinberg, Turning Back: The Retreat from Racial Justice in American Thought and Policy (Boston: Beacon Press, 1995).
} 
initiatives. And they highlight the important support role played by purportedly racial liberals - from Jimmy Carter and Bill Clinton to a young Delaware Senator named Joseph Biden - in helping to shape, consolidate and legitimise this discourse. Yet Winning While Losing also recognises the limits of the conservative ascendancy, reflecting a wider recent trend in the historiography of American conservatism that now argues for the 'failed revolution' of the political Right. ${ }^{2}$ As the essays demonstrate, conservatives initiated affirmative action policies and then failed in their attempts to reverse them, typically bowed to political pragmatism before political ideology, and at times even aided the expansion of "big government", as in the case of George W. Bush's No Child Left Behind Act. Liberalism's surprising resilience, and a transformed, often uncertain post-civil rights polity, ensured that conservatives were forced to compromise and innovate as often as they were able to "turn back the clock" on civil rights.

Despite its strengths, Winning While Losing is not without its omissions. First, the majority of the book's coverage is given over to the cause of African-American civil rights, yet as John Skrentny's work on the 'minority rights revolution' makes clear, from the 1970s onwards African-Americans were working in an increasingly competitive civil rights marketplace, facing challenges from Latinos, Asian-Americans, women, homosexuals, the disabled and even ethnic whites. ${ }^{3}$ Despite some discussion of the growing appeal of the Latino vote for conservative presidents and candidates, or the contrasting fortunes of women's rights, Winning While Losing might do more to discuss how the arrival of these competitors challenged, defined and limited the potential civil rights gains of African-Americans in an increasingly crowded field. Second, the international dimensions of civil rights, which grew in importance with the amplification of an African-American foreign policy voice in the 1970s and 1980s, receive remarkably little coverage in the book. These are areas in which civil rights advocates won notable gains from conservative executives, from the 1986 Comprehensive Anti-Apartheid Act to Bush's anti-HIV/AIDS campaigns in Africa, yet they are rarely addressed in these pages.

Nonetheless, Winning While Losing offers valuable and much-needed insights into both the trajectory of civil rights politics after the racial revolution of the 1960s, and the intersection

\footnotetext{
2 Julian Zelizer, 'Rethinking the History of American Conservatism', Reviews in American History 38 (2) (June 2010), pp. 367-389; Kim Phillips-Fein, 'Conservatism: A State of the Field', Journal of American History 98 (3) (2011), pp. 723-743.

${ }^{3}$ John Skrentny, The Minority Rights Revolution (Cambridge: Belknap Press, 2002).
} 
of that politics with the wider conservative movement against a changing political, economic and intellectual backdrop. Its essays tell stories of entrenched racial problems and difficult solutions, ambiguous victories and unlikely obstacles; stories that are awkward and even unpopular, certainly, but in our increasingly individualistic and unequal society, more important than ever to share.

Dr Joe Merton

Department of History, University of Nottingham 